\section{Descriptions of Chestnut Cultivars for Nut Production in the Eastern and Midwestern United States}

\author{
Ronald S. Revord \\ University of Missouri Center for Agroforestry, Anheuser-Busch Natural \\ Resources Building, 1111 Rollins Road, Columbia, MO 65201
}

J. Michael Nave
Independent Researcher. Republic, MO 65738

Gregory Miller

Empire Chestnut Company, 3276 Empire Road SW, Carrollton, OH 44615

Nicholas Meier, J. Bryan Webber, and Michael A. Gold
University of Missouri Center for Agroforestry, Anheuser-Busch Natural
Resources Building, 1111 Rollins Road, Columbia, MO 65201

Tom Wahl

Red Fern Farm, 13882 I Avenue, Wapella, IA 52653

Additional index words. Castanea, repository, germplasm conservation, tree breeding

\begin{abstract}
The Chinese chestnut (Castanea mollissima Blume) and other Castanea species (Castanea spp. Mill.) have been imported and circulated among growers and scientists in the United States for more than a century. Initially, importations of $C$. mollissima after 1914 were motivated by efforts to restore the American chestnut [Castanea dentata (Marsh.) Borkh.], with interests in timber-type characters and chestnut blight resistance. Chestnut for orchard nut production spun off from these early works. Starting in the early 20th century, open-pollinated seeds from seedlings of Chinese chestnut and other Castanea species were distributed widely to interested growers throughout much of the eastern United States to plant and evaluate. Germplasm curation and sharing increased quite robustly through grower networks over the 20th century and continues today. More than 100 cultivars have been named in the United States, although a smaller subset remains relevant for commercial production and breeding. The University of Missouri Center for Agroforestry curates and maintains a repository of more than 60 cultivars, and open-pollinated seed from this collection has been provided to growers since 2008. Currently, more than $\mathbf{1 0 0 0}$ farms cultivate seedlings or grafted trees of the cultivars in this collection, and interest in participatory on-farm research is high. Here, we report descriptions of 57 of the collection's cultivars as a comprehensive, readily accessible resource to support continued participatory research.
\end{abstract}

Chestnut cultivation for nut production in the midwestern United States has experienced accelerated adoption in recent years, with the number of farms increasing $57 \%$ between 2012 and 2017, and more than 300 orchards

Received for publication 29 June 2021. Accepted for publication 12 Aug. 2021

Published online 18 October 2021.

This work is supported by the United States Department of Agriculture (USDA) Agricultural Marketing Service (Agreement No. AM190200XXXXG010), the University of Missouri Center for Agroforestry, and the USDA Agricultural Research Service (ARS) Dale Bumpers Small Farm Research Center (Agreement numbers 58-6020-6-001 and 58-6020-0-007) of the USDA ARS.

R.S.R. is the corresponding author. E-mail: r.revord @missouri.edu.

This is an open access article distributed under the CC BY-NC-ND license (https://creativecommons. org/licenses/by-nc-nd/4.0/). market through Prairie Grove Chestnut Cooperative. Production capacity from 59 Missouri farmers ranges upward from 10,000 pounds. In Ohio, growers of the Route 9 Cooperative have steadily increased production to 100,000 pounds, and the state had 75 farms of bearing age (USDA National Agricultural Statistics Service, 2018). Similar trends are observed in half a dozen other states in or neighboring the Midwest, and the number of bearing farms is more than 600 (USDA National Agricultural Statistics Service, 2018).

The growth of Chinese chestnut (Castanea mollissima) production in the midwestern United States is unique compared with most fruit and nuts because orchard cultivation currently favors seedlings rather than clonal selections. This is because C. mollissima seedlings from good parents outperform grafted trees at the orchard-level because of issues with delayed graft failure (Hunt et al., 2012). However, it is important to note the grafted cultivars can be maintained in moderate quantities to support curation and trialing. Consequently, germplasm improvement is ongoing, and dedicated growers are willing to integrate evaluation and selection into their operations. This structure has placed responsibility for developing improved selections mainly at the farm level, causing it to be decentralized and occurring in many different environments simultaneously. Although growers share information and plant materials, their efforts are spontaneous and not well coordinated. This participatory network of growers has matured to the point where better coordination is warranted. A first and critical step to coordinate efforts is publishing validated histories and descriptions of the many parent cultivars used by commercial producers throughout the Midwest.

\section{Emphasizing the Benefit of Published Cultivar Descriptions}

The participatory nature of chestnut genetic improvement, although highly constructive, can introduce ambiguity about the quality and performance of cultivars. There are at least five common ways that ambiguity or conflicting information about grafted cultivar performance is introduced: 1) rootstock effects, 2) environment effect, 3) genotype by environment effects, 4) time (age), and 5) cultivar identification loss or misidentification.

Based on climate, the potential cultivation range for $C$. mollissima includes much of the eastern half of the United States (Fei et al., 2012). However, knowledge of how to match existing germplasm with different environments or growing regions is lacking. This gap exists because attempts to adapt cultivated $C$. mollissima germplasm for nut production across the United States are young on the timescale of tree genetic improvement, occurring sporadically over the past 100 years (Anagnostakis, 2012).

Conversely, C. mollissima has been deliberately cultivated throughout China for more than 2000 years (Rutter et al., 1991; Wang, 2004). During that time, artificial selection 
was imposed for many of the same traits relevant to modern breeding (e.g., architecture, early bearing, high sugar content, yield stability, nut size, easy peeling, etc.). This long history of domestication makes China home to hundreds of cultivars that are categorized by cultivation region, province, or even growing zone within the province. Generally, C. mollissima cultivars are divided into five major areas, North China, East China, Central China, South China, and Southwest China, based on the climatic characteristics of China (Craddock and Perkins, 2019). This geographic range of Chinese production spans from $30^{\circ}$ to $40^{\circ} \mathrm{N}$ latitude and United States Department of Agriculture (USDA) plant hardiness zones 10 to 5a. Regional differences in allele frequencies between $C$. mollissima from northern and southern regions provide some genetic evidence for local adaptation, with detected loci associated with putative traits like trichome density, lignin synthesis, and regional disease (LaBonte et al., 2018). Although the growing regions in China can inform germplasm development in the United States, the eastern United States climate from the $30^{\circ}$ to $40^{\circ} \mathrm{N}$ latitude is not directly comparable to corresponding latitudes in China.

Chestnut for nut production in the United States has not undergone organized, successive generations of selection to develop cultivars adapted within the broad target growing region. Additionally, many of the cultivars used today have an unknown ancestry, meaning that the founder cultivars from China cannot inform U.S. trials.

Grower trials have been based on the sharing of plant materials. All too commonly, mistakes are made regarding the identification of cultivars (e.g., scions are mistaken for one another, mistaken for a rootstock, or mistaken for their offspring) (McCleary et al., 2013). Additional confusion can arise because of the renaming of cultivars after ramet evaluation and the trialing of open-pollinated seedlings from cultivars without careful record-keeping. Loss of replication and field-level variations also influence results.

\section{Grower Germplasm Use}

The University of Missouri's Center for Agroforestry (UMCA) (New Franklin, MO) maintains a repository of many of the predominant cultivars used by growers in the eastern and midwestern United States This grafted cultivar collection was assembled between 1996 and 2005, and it consisted of 65 cultivars that underwent long-term evaluation into the 2010s (Hunt et al., 2004; Mori et al., 2017). The foremost objective of the evaluations was to identify individuals welladapted to the mid-Missouri climate with nut quality traits suitable for commercial marketing (e.g., large, round, sweet, and low defects). Throughout the trial, seed and scion from preferred selections were made available to pioneer growers throughout the Midwest for trialing. Preferred selections were revised as traits revealed themselves over time (e.g., interannual yield variability and disease or pest susceptibility), and growers began opting for half-sibling seedlings to allow for broader geographic testing and circumvent delayed graft failure. Wide dissemination of seedling stock from this collection also provided the robust infrastructure for the breeding of improved, recombinant individuals well-adapted to regions outside of midMissouri. The ensuing 15 years of on-farm evaluation led to many grower selections, where the best seedling trees were propagated and shared extensively through the eastern half of the United States. Currently, more than 10,000 offspring from this collection are growing in the eastern and midwestern United States, and growers and breeders alike would benefit from a validated, comprehensive list of cultivar descriptions.

\section{Cultivar Descriptions}

The following descriptions are not intended as a tool to inform grower adoption per se; chestnut adoption is occurring across many diverse environments where grafted cultivar performance remains to be determined. Instead, our aim is to compile known information regarding 57 cultivars still living in the UMCA repository into a single resource to be more readily accessible to university researchers and growers alike. The descriptions will be updated (on https:// centerforagroforestry.org/) as partners evaluate ramets across different environments.

Phenotypic descriptions include species, origin, growth habit, aspects of phenology and bearing, notes about nut and kernel quality, and observations of resistance/susceptibility to pests and diseases (Table 1). The descriptions are interpretive reports from U.S.-based chestnut experts closely involved with sourcing and cultivating the original plant material (G. Miller, M. Nave, R. Stehli, and $\mathrm{T}$. Wahl). Additional supporting details are derived from the University of Missouri chestnut repository located at the Horticultural and Agroforestry Research Center (HARC) (New Franklin, MO). McCleary et al. (2013) previously reported information about species ancestry. The descriptions are also adapted in part from various grower organization records (Metaxas, 2013; Miller, 2003, 2016; Nave, 1998, 2017).

'ABC Red' (C. mollissima) is an openpollinated (OP) seedling selection made by M. Nave from the cultivar Honglizi, the Nanjing Botanical Garden's red chestnut. The nuts were imported under the USDA permit from Liu Liu of Nanjing Botanical Garden and planted in California in Spring 1994. The tree is very vigorous, and new growth is red. Autumn leaves are also red, and stems and burs are reddish. Its nuts are small (10-12 g), but they have excellent flavor and good pellicle removal. Although 'ABC Red' is pollenfertile, it does not have a heavy catkin set. It is a sibling of 'Liu' (Anagnostakis and Nave, 2015; Nave, 2017). 'ABC Red' was recently provided to UMCA by M. Nave and will be field-established in replicate in 2022. Seed and scion wood have been circulated ad hoc broadly to growers throughout the United States over the past 20 years, but systematic evaluation of this cultivar has not yet occurred.

'Amy' (C. mollissima) is a G. Miller selection (72-400) from a 1972 planting of $C$. mollissima seedlings (Carrollton, $\mathrm{OH}$ ), which is the same planting that produced 72-76, 'Gideon', and 'Peach'. Its mother was acquired from Ackerman Nursery, Bridgman, MI, in 1957. 'Amy' displayed greater cold hardiness than most other C. mollissima trialed in Carrollton, $\mathrm{OH}$. It breaks bud relatively early in the spring (in Ohio). It consistently bears high yields. DNA markers reveal that it is approximately one-eighth Japanese, which is likely contributed by its unknown father (unpublished data). Its Japanese ancestry provides some explanation for its high yield and early phenology. The cultivar's nuts (small to medium) have an excellent flavor and peel well. 'Amy' matures earlier than 'Eaton' and 'Sleeping Giant'. Ramets at HARC produced first and mature yields 7 and 9 years from grafting (1998). The average nut size was $\approx 12 \mathrm{~g}$ during the early years of UMCA trials, but it decreased to $10 \mathrm{~g}$ or less with mature bearing. Blossom end rot was observed on 'Amy' in New Franklin, MO, in its 2013 crop. Mature yields varied moderately (2006-09), except for the complete crop loss during a double frost in Spring 2007. 'Amy' performed similarly in UTC trials (Metaxas, 2013).

'AU Cropper' (C. mollissima) was released by Auburn University in 1980 . The cultivar produces heavy crops of decent quality, mediumsize chestnuts (Nave, 2017). The average nut size can decrease moderately in larger crop years. In Missouri, consistent mature bearing began 8 years from grafting and incrementally increased from 2004 to 2010.

'AU Homestead' (C. mollissima) is a selection of a USDA cooperative planting established at Auburn University in 1954. It was released by Auburn University in 1980 . 'AU Homestead' is late-ripening, has a long ripening period, and is considered better suited for household use than commercial plantings. This nut is considered by Hongwen Huang, Hongwen Huang, Director, South China Botanical Gardens, Chinese Academy of Sciences, to have an exceptionally fine flavor. The nut has a glutinous quality that is preferred in China. This quality refers to the temperature that starch gelatinizes in the nut (lower than $60^{\circ} \mathrm{C}$ or $140{ }^{\circ} \mathrm{F}$ ) in chestnut. In lay terms, the glutinous quality is probably best described by the term "mouthfeel," and it imparts a rich and complex texture. Based on years of taste testing, M. Nave hypothesizes that the higher-quality European and American chestnuts have a lower gelatinization temperature than most $C$. mollissima nuts, which plays a role in their excellent flavor. Furthermore, some of the C. mollissima (based on the Chinese standards) with better flavor seem similar to European and American nuts; these nuts, 'AU Homestead' included, taste much better roasted than raw (Metaxas, 2013; Miller, 2003; Nave, 1998). 


\begin{tabular}{|c|c|c|c|c|c|c|c|}
\hline Cultivar & Origin & States cultivated & Vetting | Uses ${ }^{\mathrm{z}}$ & Growth & $\begin{array}{l}\text { Phenology and } \\
\text { bearing }\end{array}$ & Nut and kernel & $\begin{array}{l}\text { Adaptation, } \\
\text { pests, and } \\
\text { diseases }\end{array}$ \\
\hline$\overline{\mathrm{ABC} \text { Red }}$ & $\begin{array}{l}\text { M. Nave, } \\
\text { 'Honglizi' OP } \\
\text { seedling }\end{array}$ & $\mathrm{CA}$ & $2 \mid \mathrm{UE}$ & Vigorous & $\begin{array}{l}\text { Pollen-fertile, } \\
\text { light catkin } \\
\text { production }\end{array}$ & $\begin{array}{l}\text { Small; excellent } \\
\text { taste, good } \\
\text { pellicle } \\
\text { removal }\end{array}$ & - \\
\hline Amy' & $\begin{array}{l}\text { G. Miller, } \\
\text { Ackerman } \\
\text { Nursery }\end{array}$ & $\mathrm{MO}, \mathrm{OH}$ & $3 \mid 4,3,2$ & $\begin{array}{l}\text { Semi-upright, } \\
\text { intermediate } \\
\text { crown }\end{array}$ & $\begin{array}{l}\text { Early budbreak; } \\
\text { consistent and } \\
\text { high yields }\end{array}$ & $\begin{array}{l}\text { Medium, smaller } \\
\text { with age; } \\
\text { excellent } \\
\text { flavor, peels } \\
\text { well }\end{array}$ & $\begin{array}{c}\text { Cold hardy, } \\
\text { BER } \\
\text { observed }\end{array}$ \\
\hline AU Cropper' & $\begin{array}{l}\text { J. Norton, } \\
\text { Auburn } \\
\text { University }\end{array}$ & $\mathrm{AL}$ & $3 \mid 4,3,2$ & $\begin{array}{l}\text { Semi-upright, } \\
\text { intermediate } \\
\text { crown }\end{array}$ & $\begin{array}{l}\text { Heavy, consistent } \\
\text { yields in MO }\end{array}$ & $\begin{array}{l}\text { Medium; decent } \\
\text { quality }\end{array}$ & - \\
\hline AU Homestead & $\begin{array}{l}\text { J. Norton, } \\
\text { Auburn } \\
\text { University }\end{array}$ & $\begin{array}{c}\text { AL, IA, MO, } \\
\text { OH, TN }\end{array}$ & $3 \mid 3,2$ & - & $\begin{array}{l}\text { Late but } \\
\text { extended } \\
\text { ripening } \\
\text { period }\end{array}$ & $\begin{array}{l}\text { Small to } \\
\text { medium; } \\
\text { exceptional } \\
\text { flavor, } \\
\text { glutinous }\end{array}$ & $\begin{array}{l}\text { Adapted to } \\
\text { moderate } \\
\text { environments }\end{array}$ \\
\hline AU Super & $\begin{array}{l}\text { J. Norton, } \\
\text { Auburn } \\
\text { University }\end{array}$ & $\begin{array}{l}\text { AL, IA, MO, } \\
\text { OH }\end{array}$ & $4 \mid 3,2$ & $\begin{array}{l}\text { Upright, } \\
\text { intermediate } \\
\text { crown }\end{array}$ & $\begin{array}{l}\text { Late ripening; } \\
\text { nuts can drop } \\
\text { in bur } \\
\text { incompatibility }\end{array}$ & $\begin{array}{l}\text { Large, highly } \\
\text { variable in } \\
\text { MO } \\
\text { Benton Harbor }\end{array}$ & $\begin{array}{l}\text { Susceptible to } \\
\text { serve cold, } \\
\text { graft } \\
\text { MSU OP } \\
\text { germplasm }\end{array}$ \\
\hline IA, MO, TN, MI & $3 \mid 2$ & $\begin{array}{l}\text { Upright, tight } \\
\text { crown }\end{array}$ & $\begin{array}{l}\text { Early ripening; } \\
\text { high, stable } \\
\text { yields (MI), } \\
\text { nuts can } \\
\text { ripen in } \\
\text { burs }\end{array}$ & $\begin{array}{l}\text { Dark red, } \\
\text { purple; } \\
\text { average taste, } \\
\text { peels well, } \\
\text { low defects }\end{array}$ & $\begin{array}{l}\text { Stability in MI; } \\
\text { poor } \\
\text { performance } \\
\text { in MO }\end{array}$ & & \\
\hline Bergantz & $\begin{array}{l}\text { M. Nave, CA } \\
\quad \text { orchard } \\
\text { seedling }\end{array}$ & $\mathrm{CA}$ & $1 \mid \mathrm{UE}$ & - & $\begin{array}{l}\text { Mid-season } \\
\text { ripening; } \\
\text { male-sterile }\end{array}$ & $\begin{array}{l}\text { Extra-large } \\
\text { during CA } \\
\text { evaluations; } \\
\text { excellent } \\
\text { flavor, peels } \\
\text { well }\end{array}$ & - \\
\hline Carr & $\begin{array}{l}\text { H.F. Stoke, } \\
\text { Tientsin, } \\
\text { China seedlot }\end{array}$ & $\mathrm{MO}$ & $3 \mid 3$ & $\begin{array}{l}\text { Upright, } \\
\text { intermediate } \\
\text { crown }\end{array}$ & - & $\begin{array}{l}\text { Small to } \\
\text { medium; } \\
\text { excellent } \\
\text { flavor, some } \\
\text { unique } \\
\text { attributes }\end{array}$ & $\begin{array}{l}\text { Delayed graft } \\
\text { failure }\end{array}$ \\
\hline Crane & - & $\mathrm{MO}$ & $2 \mid 1$ & $\begin{array}{l}\text { Strong central } \\
\text { leader, } \\
\text { upright, tight } \\
\text { crown }\end{array}$ & - & $\begin{array}{l}\text { Small to } \\
\text { medium, good } \\
\text { storage; } \\
\text { average flavor }\end{array}$ & $\begin{array}{l}\text { Blight } \\
\text { susceptible }\end{array}$ \\
\hline Eaton & $\begin{array}{l}\text { F. Eaton, } \\
\text { 'Sleeping } \\
\text { Giant' OP } \\
\text { seedling }\end{array}$ & $\mathrm{OH}, \mathrm{TN}$ & $4 \mid 3,2$ & $\begin{array}{l}\text { Semi-upright, } \\
\text { intermediate } \\
\text { crown }\end{array}$ & - & $\begin{array}{l}\text { Medium; } \\
\text { excellent } \\
\text { flavor, a } \\
\text { favorite }\end{array}$ & $\begin{array}{l}\text { Delayed graft } \\
\text { failure }\end{array}$ \\
\hline Emalyn's Purple & $\begin{array}{l}\text { M. Nave, Byron, } \\
\text { GA OP } \\
\text { seedling }\end{array}$ & $\mathrm{CA}$ & $1 \mid 2, \mathrm{UE}$ & - & $\begin{array}{c}\text { Mid-season } \\
\text { ripening }\end{array}$ & $\begin{array}{l}\text { Extra-large } \\
\text { during CA } \\
\text { evaluations; } \\
\text { good flavor, } \\
\text { sweetness }\end{array}$ & - \\
\hline Everfresh & $\begin{array}{l}\text { MSU OP } \\
\text { germplasm }\end{array}$ & MI, MO & $2 \mid 1$ & - & $\begin{array}{l}\text { Consistent but } \\
\text { moderate yield }\end{array}$ & Excellent storage & $\begin{array}{l}\text { Blight- } \\
\text { susceptible }\end{array}$ \\
\hline Gideon & $\begin{array}{l}\text { G. Miller, } \\
\text { Ackerman } \\
\text { Nursery }\end{array}$ & $\mathrm{OH}, \mathrm{MO}, \mathrm{TN}$ & $4 \mid 4,3,2$ & $\begin{array}{l}\text { Semi-upright, } \\
\text { intermediate } \\
\text { crown }\end{array}$ & $\begin{array}{l}\text { Mid-season } \\
\text { ripening; } \\
\text { consistent } \\
\text { yield, good } \\
\text { offspring }\end{array}$ & $\begin{array}{l}\text { Medium to } \\
\text { large, uniform } \\
\text { shape }\end{array}$ & $\begin{array}{l}\text { Progeny tested } \\
\text { well, with a } \\
\text { high } \\
\text { frequency of }\end{array}$ \\
\hline
\end{tabular}




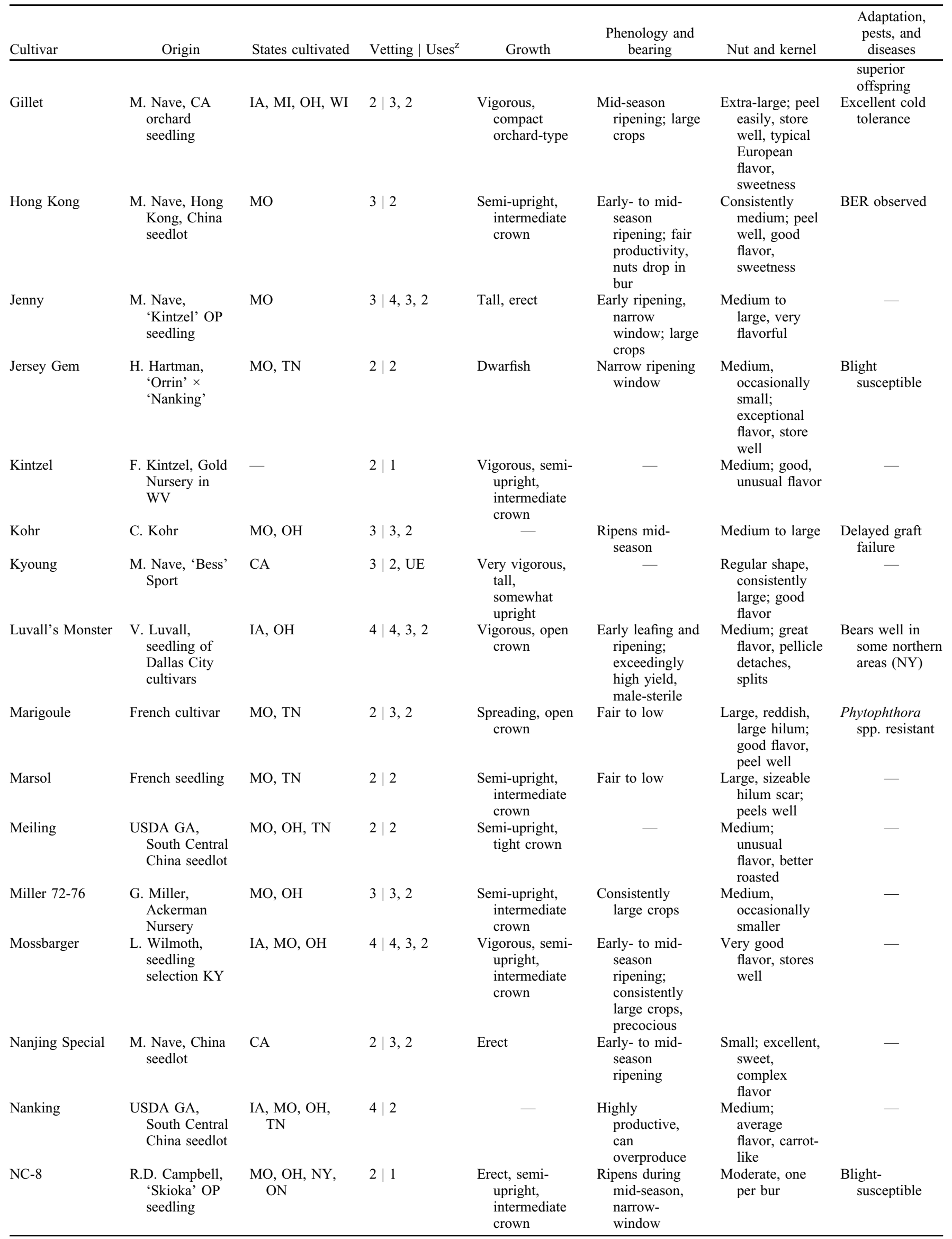




\begin{tabular}{|c|c|c|c|c|c|c|c|}
\hline Cultivar & Origin & States cultivated & Vetting | Uses ${ }^{\mathrm{Z}}$ & Growth & $\begin{array}{l}\text { Phenology and } \\
\text { bearing }\end{array}$ & Nut and kernel & $\begin{array}{l}\text { Adaptation, } \\
\text { pests, and } \\
\text { diseases }\end{array}$ \\
\hline Orrin & $\begin{array}{l}\text { J. McKay, South } \\
\text { Central China } \\
\text { seedlot }\end{array}$ & $\mathrm{MO}, \mathrm{OH}$ & \begin{tabular}{l|l}
$3 \mid 2$ \\
\end{tabular} & $\begin{array}{l}\text { Very erect, } \\
\text { upright, tight } \\
\text { canopy }\end{array}$ & $\begin{array}{l}\text { Good } \\
\text { productivity }\end{array}$ & $\begin{array}{l}\text { Medium, dark } \\
\text { mahogany; } \\
\text { good flavor }\end{array}$ & - \\
\hline Patterson & $\begin{array}{l}\text { M. Nave, China } \\
\text { seedlot }\end{array}$ & $\mathrm{CA}$ & $2 \mid 4,3,2$ & $\begin{array}{l}\text { Spreading, } \\
\text { orchard-type, } \\
\text { vigorous }\end{array}$ & $\begin{array}{l}\text { Highly } \\
\text { productive, } \\
\text { fertile catkins }\end{array}$ & $\begin{array}{l}\text { Large, medium } \\
\text { in older trees; } \\
\text { sweet when } \\
\text { cured }\end{array}$ & - \\
\hline Peach & $\begin{array}{l}\text { G. Miller, } \\
\text { Ackerman } \\
\text { Nursery }\end{array}$ & $\mathrm{MO}, \mathrm{OH}, \mathrm{TN}$ & $4 \mid 3,2$ & Upright & $\begin{array}{l}\text { Early to mid- } \\
\text { season } \\
\text { ripening; } \\
\text { productive but } \\
\text { delayed } \\
\text { maturity, can } \\
\text { fall flower }\end{array}$ & $\begin{array}{l}\text { Medium to } \\
\text { large, } \\
\text { consistent; } \\
\text { typical flavor }\end{array}$ & - \\
\hline Precoce Migoule & French cultivar & - & $2 \mid 2$ & $\begin{array}{l}\text { Vigorous, tight } \\
\text { crotch angles }\end{array}$ & $\begin{array}{l}\text { Productive, } \\
\text { pollen-fertile }\end{array}$ & $\begin{array}{l}\text { Medium to } \\
\text { large; good } \\
\text { flavor, } \\
\text { multiple } \\
\text { embryos }\end{array}$ & $\begin{array}{l}\text { Phytophthora } \\
\text { spp.-resistant }\end{array}$ \\
\hline Qing & $\begin{array}{l}\text { M. Nave, } \\
\text { seedling } \\
\text { selection KY }\end{array}$ & $\mathrm{MO}, \mathrm{OH}$ & $4 \mid 4,3,2$ & $\begin{array}{l}\text { Semi-upright, } \\
\text { open crown, } \\
\text { small stature }\end{array}$ & $\begin{array}{l}\text { Early to mid- } \\
\text { season } \\
\text { ripening, very } \\
\text { late leafing; } \\
\text { heavy } \\
\text { producer }\end{array}$ & $\begin{array}{l}\text { Large; good } \\
\quad \text { flavor, } \\
\text { exceptionally } \\
\text { sweet, great } \\
\text { storage }\end{array}$ & $\begin{array}{c}\text { Minimal BER, } \\
\text { spring frost } \\
\text { avoidance, } \\
\text { graft failure }\end{array}$ \\
\hline Schlarbaum & $\begin{array}{l}\text { M. Nave, Byron, } \\
\text { GA OP } C \text {. } \\
\text { crenata } \\
\text { germplasm }\end{array}$ & IA & $2 \mid 3,2$ & Tall, slender & $\begin{array}{l}\text { Mid-season } \\
\text { ripening; } \\
\text { average } \\
\text { production, } \\
\text { male-sterile }\end{array}$ & $\begin{array}{l}\text { Very large; easy } \\
\text { pellicle } \\
\text { removal }\end{array}$ & - \\
\hline Sleeping Giant & $\begin{array}{l}\text { C. mollissima } \times \\
\text { (C. crenata } \times \\
\text { C. dentata })\end{array}$ & $\begin{array}{l}\mathrm{CT}, \mathrm{MO}, \mathrm{OH} \\
\text { TN }\end{array}$ & $4 \mid 4,3,2$ & $\begin{array}{l}\text { Upright, } \\
\text { intermediate }\end{array}$ & $\begin{array}{l}\text { Early to mid- } \\
\text { season } \\
\text { ripening, } \\
\text { consistent } \\
\text { yielding }\end{array}$ & $\begin{array}{l}\text { Medium, smaller } \\
\text { in the north; } \\
\text { good-flavor }\end{array}$ & $\begin{array}{l}\text { General } \\
\text { adaptation, } \\
\text { BER } \\
\text { observed }\end{array}$ \\
\hline Szego & $\begin{array}{l}\text { M. Nave, } \\
\text { 'Linden' OP } \\
\text { seedling }\end{array}$ & IA, MO & $4 \mid 2$ & $\begin{array}{l}\text { Open crown, } \\
\text { vigorous, } \\
\text { upright }\end{array}$ & $\begin{array}{l}\text { Late ripening; } \\
\text { good } \\
\text { productivity, } \\
\text { nuts drop in } \\
\text { the bur, male- } \\
\text { fertile }\end{array}$ & $\begin{array}{l}\text { Large; sweet, } \\
\text { very flavor, } \\
\text { easy peeling }\end{array}$ & $\begin{array}{l}\text { Blight- } \\
\text { susceptible, } \\
\text { Phytophthora } \\
\text { spp.-resistant, } \\
\text { cold-hardy }\end{array}$ \\
\hline Vancouver & $\begin{array}{l}\text { M. Nave, } \\
\text { Vancouver } \\
\text { Canada } \\
\text { seedlot }\end{array}$ & CA & $1 \mid \mathrm{UE}$ & Vigorous & - & Large; flavorful & - \\
\hline $\mathrm{WC}$ & $\begin{array}{l}\text { W.C. Donaho, } \\
\text { KY seedling } \\
\text { selection }\end{array}$ & $\mathrm{MO}, \mathrm{OH}$ & $1 \mid \mathrm{UE}$ & Vigorous & - & $\begin{array}{l}\text { Large, dark; } \\
\text { sweet, stores } \\
\text { well }\end{array}$ & - \\
\hline Willamette & $\begin{array}{l}\text { Dunstan } \\
\text { population }\end{array}$ & $\mathrm{MO}, \mathrm{TN}$ & $3 \mid 1$ & $\begin{array}{l}\text { Upright, tight } \\
\text { crown }\end{array}$ & $\begin{array}{l}\text { Good } \\
\text { productivity }\end{array}$ & $\begin{array}{l}\text { Small to } \\
\text { medium, } \\
\text { inconsistent } \\
\text { year to year; } \\
\text { unusual flavor }\end{array}$ & - \\
\hline $\begin{array}{l}\text { Yixian Good } \\
\text { Flavor }\end{array}$ & $\begin{array}{l}\text { M. Nave, } \\
\text { Yixian, China } \\
\text { seedlot }\end{array}$ & MO & $3 \mid 3,2$ & $\begin{array}{l}\text { Upright, tight } \\
\text { crown }\end{array}$ & $\begin{array}{l}\text { Wide ripening } \\
\text { window, early } \\
\text { to late season }\end{array}$ & $\begin{array}{l}\text { Medium to } \\
\text { large; very } \\
\text { flavorful, }\end{array}$ & - \\
\hline
\end{tabular}




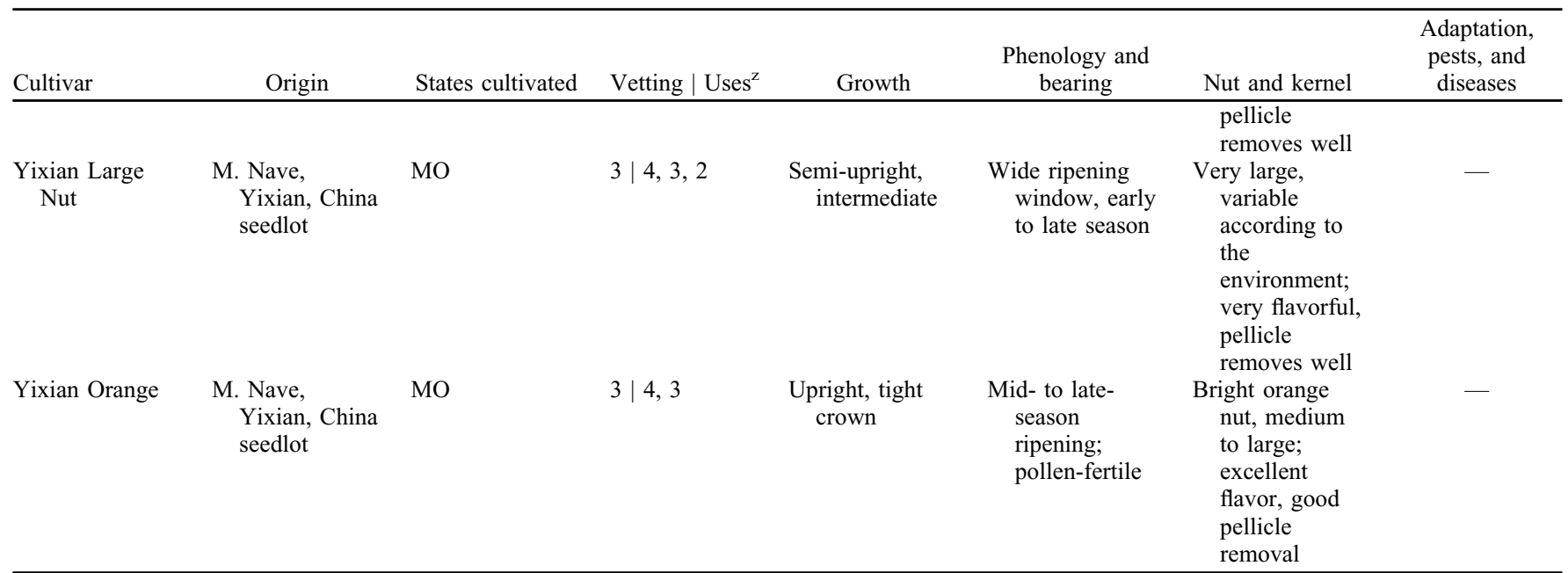

"The "degree of vetting" is a relative term reflecting the level to which cultivars have been evaluated to date and across environments. Class 4 denotes well-vetted cultivars for which performance and attributes are well understood. Class 3 entails cultivars with some vetting, although further evaluation is needed across environments and time. Class 2 represents cultivars with limited vetting. Class 1 describes cultivars that are new or have unknown performance across environments. "Uses" describes the relevant utility of the cultivars at present: class 4 denotes scion cultivar, class 3 signifies value as a seed orchard parent, class 2 represents uses as a breeding parent, class 1 indicates the cultivar is obsolete, and UE notes that the cultivar is still under evaluation.

$\mathrm{AL}=$ Alabama $\mathrm{BER}=$ blossom end rot; $\mathrm{CA}=$ California $\mathrm{CT}=$ Connecticut IA = Iowa $\mathrm{KY}=$ Kentucky; $\mathrm{MI}=\mathrm{Michigan} ; \mathrm{MO}=\mathrm{Missouri} ; \mathrm{NY}=\mathrm{New}$ York; $\mathrm{OH}=$ Ohio; $\mathrm{ON}=$ Ontario; $\mathrm{OP}=$ open-pollinated; $\mathrm{TN}=$ Tennessee; $\mathrm{WI}=$ Wisconsin; $\mathrm{WV}=$ West Virginia.

The nut size fluctuates with crop size and tree age.

'AU Leader' (C. mollissima) was released by Auburn University in 1980 (Norton et al., 1983). It produces medium-size nuts that range upward from $\approx 13 \mathrm{~g}$, depending on location and year. They have an excellent flavor, raw or roasted, and store well (Nave, 1998). 'AU Leader' was quite unproductive in Missouri.

'AU Super' (C. mollissima) is from Auburn University, but it was never formally released as a cultivar. It was dubbed "AUSuper" by Hongwen Huang during his time at Auburn. It has relatively large nuts that ripen late during the season. Nut and tree morphology indicate that it is not related to the other Auburn releases ('AU Cropper', 'AU Leader', and 'AU Homestead'). This cultivar has performed especially well in east-central Iowa. It tends to overbear in some years, significantly reducing the average nut size. However, it is vulnerable to severe dieback after severe winter low temperatures. Ramets grow quite vigorously, allowing them to recover well from cold dieback.

'Benton Harbor' (C. mollissima) is a seedling selection from the Michigan State University experiment station in Benton Harbor, MI. Its mother is described as the largest tree at the station. 'Benton Harbor' yields are high and stable, from 70 to $90 \mathrm{lb}$ in Michigan, and it produces earlier than most $C$. mollissima selections. Its dark red and purple nuts lack double embryos and splits, peel well, and have an average taste. Nuts can drop within the heavy, thick burs. Field observations note blight resistance (Fulbright, 2021).

'Bergantz' (C. sativa Mill. $\times$ C. crenata Siebold \& Zucc.) is an orchard seedling (possibly of the cultivar Nevada) in the Sierra Nevada foothills. The seed source was Bob Bergantz. The cultivar produces extra-large nuts in California that peel easily and have an excellent flavor. The nuts fall during mid-season ( 2 weeks after 'Colossal'). It is male-sterile. Greater evaluation in the East and Midwest is needed. 'Bergantz' ramets were introduced to the UMCA repository in 2020.

'Beth' (C. mollissima) is a seedling selection from Kentucky made by John Brittain at Nolin River Nut Tree Nursery. Its nut is small, but it has good flavor and texture (Nave, 1998). 'Beth' ramets were introduced to the UMCA repository in 2020.

'Bouche de Betizac' $(C$. sativa $\times$ C. cren$a t a)$ is an OP seedling of the French cultivar 'Bouch Rouge' and a C. crenata pollen parent. It was introduced to the United States by Craddock and Pellegrino (1992). Grafted trees have been planted widely in the western United States, but not in the Midwest. The tree has vigorous, straight growth. It is noted to handle the heat of the California central valley very well, but it also performs well in cooler climates. Nuts fall mid-season in warm climates. 'Bouche de Betizac' is pollen-sterile. It produces very broad, dark brown nuts that peel well and have good flavor. Ramets in the UMCA repository have a nut size ranging from 20 to $25 \mathrm{~g}$. Three nuts are standard per bur (Nave, 1998). Nuts in the center of burs are usually flat. 'Bouche de Betizac' displays field immunity to Asian gall wasp (Torello-Marinoni et al., 2018). Grafted trees have been planted widely in the western United States, but not in the Midwest. 'Bouche de Betizac' seedlings have been planted in the Midwest, but with tempered expectations because they were pollinated with $C$. sativa.
'Carolina' (C. mollissima) is a third-generation OP offspring selected in Alachua, FL, from the widely available Dunstan population. The population is derived from a putative and lost $C$. dentata tree (described as blight resistant) and three $C$. mollissima cultivars, 'Nanking', 'Kuling', and 'Meiling' (Note: Morphological characteristics and DNA markers indicate no $C$. dentata ancestry in the Dunstan population). 'Carolina' is reported as particularly sweet, but evaluations by $M$. Nave suggested that the cultivar's siblings, 'Carpentar' and 'Revival', are sweeter (Miller, 2003; Nave, 1998).

'Carr' (C. mollissima) is a seedling that originated from a seedlot in Tientsin, China. The USDA (Beltsville, MD) sent the seed to R.D. Carr of Magnolia, NC, in 1915. 'Carr' was first grafted in 1932 by H.F. Stoke of Roanoke, VA, and was commercially introduced in 1935. Unfortunately, the cultivar is extremely difficult to graft and, despite wide distribution, only a few trees are still known to exist (Seligmann, 1994). The tree has a very upright growth pattern. It has small to medium nuts (10-12 g) with excellent flavor, although they are slightly different from the average C. mollissima nut (Nave, 1998).

'Crane' (C. mollissima) is a seedling selected from nuts sent by Peter Liu to the USDA in 1936, and subsequently evaluated in Philema, GA. It is from the same seedlot as 'Meiling' and 'Nanking', but it grows more upright, maintaining a stronger central leader. J.W. McKay named 'Crane' in 1963 to honor H.L. Crane, a chestnut researcher from the 1930 s to $1950 \mathrm{~s}$. The nuts $(10-12 \mathrm{~g})$ are a distinctive reddish color and have good keeping quality. However, the nut flavor is average for a $C$. mollissima nut; therefore, it 
is seldom planted today (Miller, 2003; Nave, 1998).

'Dallas City River' and 'Dallas City Street' (hybrids perhaps involving C. crenata and $C$. dentata) are of unknown origin and are likely products of the breeding efforts by E.A. Riehl (Godfrey, IL) or George W. Endicott (Villa Ridge, IL) at the turn of the 20th century. Both breeders used American and Japanese seedlings. Riehl used the cultivars 'Dan Patch' (C. crenata $\times C$. dentata), 'Boone' (an 1896 Endicott $C$. crenata $\times C$. dentata hybrid), and 'McFarland' (a Luther Burbank hybrid, probably $C$. crenata $\times C$. sativa $\times C$. dentata $\times C$. mollissima), and originated many high-quality American hybrids such as 'Rochester', 'Gibbens', 'Fuller', 'Champion', 'Progress', and others (Colby, 1924). Dr. A.S. Colby once described some of these hybrids as combining "the size of the Japanese with the quality of the American parent" (Colby, 1936). It is also possible the Dallas City cultivars could be a product of Benjamin Buckman (Farmingdale, IL) or Dr. A.S. Colby himself, who taught at the University of Illinois, Urbana-Champaign (Nave, 1998).

'Douglass 1A' $(C$. mollissima $\times C$. dentata) is a selection by Earl Douglas, who made many $C$. mollissima $\times C$. dentata hybrids in New York in the 1950s and 1960s. Its nut size varies quite a bit within a single year's crop. 'Douglass 1A' nuts also experience some defective traits such as splitting and multiple embryos, although they have good flavor and peel well (Nave, 1998).

'Eaton' $(C$. mollissima $\times C$. crenata $\times C$. dentata) is a "favorite eater" among chestnut consumers (M. Gold and M. Nave, personal communication). Its characteristics are predominantly of $C$. mollissima, and its nuts $(12-13 \mathrm{~g})$ have excellent flavor, raw or roasted. The cultivar originated from a seedling given to Frederick Eaton (Wallingford, CT) by Arthur Graves (Jaynes, 1970), and it is thought to be an OP seedling of 'Sleeping Giant'. Delayed graft failure has been noted, even to a degree in Missouri.

'Eaton River' $(C$. mollissima $\times C$. crenata $\times C$. dentata) is presumably a seedling of 'Eaton' propagated and sold as grafted trees by John Brittain at Nolin River Nut Tree Nursery.

'Emalyn's Purple' (C. mollissima) is a seedling descended from the USDA planting in Byron, GA. The seedling was grown out and evaluated by M. Nave in California. It ripens and drops its nuts during mid-season. The nuts are large $(\approx 29 \mathrm{~g})$ in the California climate and have good flavor and sweetness. Their pubescent is similar to 'Jenny' (Nave, 2017). The tree's form and productivity have not yet been evaluated. Scion has been distributed to many growers, and ramets were brought into the UMCA collection in 2019. Greater evaluation in the East and Midwest is needed.

'Everfresh' (C. mollissima) is a selection from the Michigan State University experiment station at Benton Harbor. The cultivar displayed consistent (but not high) yields in Michigan and unique characters that enabled frost avoidance when most $C$. mollissima cultivars experienced losses. The tree is a slow-growing tree and has heavy catkin sets. 'Everfresh' nuts, true to their name, have a uniquely long shelf life. Stored properly, nuts from this cultivar keep into the summer following their harvest (Fulbright, 2021). Unfortunately, ramets of 'Everfresh' were susceptible to blight in $\mathrm{MO}$.

'Gideon' (C. mollissima) is a G. Miller selection (72-283) from the same seedlot that derived 'Amy' and 'Peach' (i.e., its mother was acquired from Ackerman Nursery, Bridgman, MI, in 1957). 'Gideon' has been a consistent bearer compared with most other C. mollissima trialed in Carrollton, $\mathrm{OH}$, and its offspring have been consistently superior. The cultivar ripens during mid-season, slightly later than 'Peach'. Its nuts (12-18 g) have a uniformly shape and are appealing (Miller, 2003).

'Gillet' $(C$. sativa $\times C$. crenata) also grew from seed provided by Bob Bergantz. Like 'Bergantz', it is expected to be a seedling of the cultivar 'Nevada'. 'Gillet' grows vigorously but has a compact orchard-type form. The cultivar produces large crops (despite ample catkin sets) and large, single-embryo nuts that peel easily and store well. The nuts have a basic European chestnut flavor that sweetens with storage. Furthermore, the nuts drop mid-season, free from relatively compact burs. 'Gillet' is also grown in Michigan, Wisconsin, Ohio, Indiana, and Illinois, but replicated data regarding performance are needed.

'Hong Kong' ( $C$. mollissima) is considered the best seedling selection from a seedlot from Hong Kong. The tree is pollen-fertile and drops its nuts during the early to mid-season. The nuts peel well, and the nut flavor is very good, with a nice sweetness. Grafted trees at the University of Missouri grew vigorously and had fair productivity without blight. Nuts from the ramets at the UMCA are consistently medium (Anagnostakis and Nave, 2015; Nave, 2017).

'Jenny' ( $C$. mollissima), named by $\mathrm{M}$. Nave, is an OP seedling of the old Ohio cultivar 'Kintzel' (also known as Byron 1-1 and 1-2). 'Jenny' is a tall tree with a very erect growth pattern, unlike most $C$. mollissima trees. It is male-fertile but productive, and the nuts are medium to large (depending on the climate), very flavorful, and a favorite to eat. Limited data show that nuts are regularly medium in Missouri. Despite their size, the nuts drop early during the season. Additionally, intra-tree nut ripening and drop occur within a narrow window (Anagnostakis and Nave, 2015; Nave, 2017). Scion of 'Jenny' has been provided to various growers across the eastern half of the United States Because of unique morphologies, experts suspect 'Jenny' might have a complex ancestry that includes $C$. dentata.

'Jersey Gem' ( $C$. mollissima) is a seedling of 'Orrin' $\times$ 'Nanking' developed by Henry Hartmann of New Jersey. The cultivar has a unique dwarfish growth pattern, and its nuts tend to ripen within a narrow window. Hartmann felt that the nuts (small to medium) stored very well and had exceptional flavor (Nave, 1998). Unfortunately, 'Jersey Gem' has exhibited some susceptibility to chestnut blight in New York.

'Kintzel' (C. mollissima) was grown by and named after Northern Nut Grower Association member Frank Kintzel. The tree is vigorous and large, and some suspect other Castanea spp. in its genetic background. The nut (13-14 g) has a good but unusual flavor. Two grafted 'Kintzel' trees (Byron 1-1 and 1-2) were in the Byron, GA, USDA orchard (Nave, 1998).

'Kohr' (C. mollissima) is a top-performer from the 2000-tree orchard planted by Clarence Kohr in Pine Grove, PA, in the 1960s. Nuts are medium to large in size and fall during mid-season. Productivity can be modest or low in some years. Grafts often experience delayed failure or poor growth.

'Kyoung' (C. mollissima) is a bud sport from the $C$. mollissima cultivar 'Bess'. 'Bess' (an OP seedling of 'Beth') is not a very productive tree; it produces irregularly shaped nuts of variable size. 'Kyoung', however, has regularly shaped, consistently large nuts. 'Kyoung' nuts also have better flavor. Nuts and scion from 'Kyoung' have been provided to growers broadly. Grafts and seedlings of 'Kyoung' are exceptionally vigorous and somewhat upright (Nave, 2017). Multiple growers from different environments note that 'Kyoung' offspring are their tallest and most vigorous. Greater evaluations in the East and Midwest are needed. 'Kyoung' ramets were introduced to the UMCA repository in 2020 .

'Lindstrom \#40' and 'Lindstrom \#43' (C. mollissima), also known as Byron 40 and 'Musella' and also known as Byron 43 and 'LaGrange', respectively, are selections from the Byron, GA, USDA orchard. Both selections heavily produced small to medium nuts. The 'Lindstrom \#43' nut size is variable and often small in Missouri.

'Luvall's Monster' [C. mollissima $\times(C$. crenata $\times C$. dentata) $]$ is a first-generation seedling of one of two old, putative Japanese $\times$ American hybrids growing on the Mississippi River in Dallas City, IL. Its pollen parent is unknown. The cultivar grows vigorously and with a preferred open crown architecture. It is also pollen-sterile, which makes 'Luvall's Monster' exceedingly high-yielding. The nut is twice as large as that of its mother. It also has a great flavor, raw or roasted, and the pellicle often comes off the kernel in one piece. However, the nut is quite wide, does not store well, and has frequent double embryos and splits. There is also a tendency to develop a "hollow heart," which is typical of Japanese and American nuts. Scion and OP seedlings have been widely circulated among Northern Nut Growers Association members. Grafts of the tree were tested in Byron, GA, to determine gall wasp resistance and the effects of climate on nut size. According to B. Caldwell, the tree does bear well in upper New York state, with good-size nuts for that area. More testing is needed in short-season areas (Hunt et al., 2004; Miller, 2017; Nave, 1998).

'Marigoule' $(C$. crenata $\times C$. sativa $)$ originates from France. It was introduced to 
the United States by Craddock and Pellegrino (1992). It has a high level of resistance to Phytophthora spp. and a reputation for producing good offspring. Its nuts (18-22 g) have a pretty reddish color and large hilum. Their flavor is good, and they peel well (Nave, 1998). Yields are fair to low in Missouri.

'Marsol' $(C$. sativa $\times$ C. crenata $)$ is also a French seedling. Its nuts have a large hilum scar and peel well (Metaxas, 2013). Yields are fair to low in Missouri.

'Meiling' (C. mollissima) was selected from seed imported by Peter Liu from southcentral China, the seedlot of 'Crane' and 'Nanking'. 'Meiling' was also introduced commercially by the USDA in 1949. In Missouri, nut size varies from small to medium. The nut has an unusual flavor that is better roasted than raw (Miller, 2003; Nave, 1998).

'Miller 72-76' (C. mollissima) is a G. Miller selection from a 1972 planting of C. mollissima seedlings (Carrollton, $\mathrm{OH}$ ), which is the same planting produced 'Amy', 'Gideon', and 'Peach'. Its mother was acquired from Ackerman Nursery, Bridgman, MI, in 1957. It bears consistent large crops of medium-size nuts. However, nut size is smaller during light crop years.

'Mossbarger' (C. mollissima) is a 1983 selection from Kentucky. The cultivar is presumed to be pure $C$. mollissima, but other species might be in its genetic background. Although the tree looks predominantly like C. mollissima, 'Mossbarger' and its offspring have unusually thick stems and branches. Nuts have a very good flavor, raw or cooked (Nave, 1998). 'Mossbarger' consistently yielded large crops in the UMCA and UTC trials. Ramets are quite vigorous and precocious compared with most $C$. mollissima selections.

'Nanjing Special' (C. mollissima) is a seedling selection of $M$. Nave originating from a seedlot from the Nanjing Botanical Garden collected in 1993. It produces small nuts with superb flavor, and $M$. Nave describes it as one of the best tasting C. mollissima nuts available in the United States. Its profile is only mildly sweet, but it has a very rare complexity of flavors. Nuts drop early and continue into mid-season. The nut color is dull brown and fades quickly and unevenly; therefore, it is not a pretty nut after a few storage days. The tree is an erect grower (Nave, 2017). Greater evaluation in the East and Midwest is needed. 'Nanjing Special' ramets were introduced to the UMCA repository in 2020.

'Nanking' (C. mollissima) shares a seedlot and history with 'Crane' and 'Meiling'. It is highly productive, sometimes overly so, such that nut size goes down. Its nut flavor (13-15 g) is average for C. mollissima nuts, and it has a reputation for producing good seedlings (Nave, 2017). However, its offspring often have an off-flavor that is difficult to describe and referred to as a carrot-type flavor. This flavor is found in many C. mollissima nuts in the eastern United States, including many Dunstan seedlings (M. Nave, personal communication) (Miller, 2003).
'NC-8' (C. mollissima), also known as 'Campbell NC-8', is a second-generation OP seedling of 'Skioka', the reputed C. mollissima $\times$ C. sativa hybrid of J.U. Gellatly (Gellatly, 1964). Morphologically, 'NC-8' appears primarily $C$. mollissima; however, some traits suggest $C$. sativa and $C$. dentata are in its genetic background. Its growth is erect, and nuts ripen midseason within a short period. Burs often contain single nuts. The tree was selected by Doug Campbell in Ontario, Canada, for its large nuts, but the nut size is moderate to small $(10-11 \mathrm{~g})$ in Missouri. However, the nut size might increase in southern or western climates (Nave, 1998).

'Orrin' (C. mollissima) originated from an orchard belonging to Orrin Good of Lock Haven, PA, and was named by J.W. McKay in 1963. It probably originated from Peter Liu's 1935 importations from seedlots with origin similar to 'Kuling', 'Meiling', and 'Nanking'. The tree has a very erect growth pattern. The nuts are quite small based on Missouri evaluations, although the tree is productive. They have a distinct dark mahogany color and a good flavor (Miller, 2003; Nave, 1998).

'Patterson' (C. mollissima) is an $\mathrm{M}$. Nave selection from seed collected at the Nanjing Botanical Garden (provided by Nanjing Botanical Garden scientist Liu Liu). The selection has morphologies that differ from those of other $C$. mollissima trees cultivated in the United States, like its wide leaves. 'Patterson' also has a spreading, orchard-type architecture; however, it grows quite vigorously. The cultivar is highly productive despite setting fertile catkins, and its nuts vary in size (from medium to large) and become very sweet when cured (Miller, 2017; Nave, 2017). Greater evaluations in the East and Midwest are needed. 'Patterson' ramets were introduced to the UMCA repository in 2020 .

'Payne' (C. mollissima), also known as Byron 3-3, was selected from the old orchard at the Southeastern Fruit and Tree Nut Research Laboratory in Byron, GA. 'Payne' was selected for its large nuts during evaluations at Byron. Interestingly, grafted trees have not reproduced the nut size of the ortet in some cases. In Missouri, nut size decreases from 19 to $10-13 \mathrm{~g}$ as trees mature. According to Metaxas (2013), 'Payne' was one of the largest-fruited and highest-yielding $C$. mollissima cultivars in the UTC trial. The nuts drop during the mid-season to late season and have good flavor (Nave, 2017).

'Peach' (C. mollissima) is a G. Miller selection from a 1972 planting of C. mollissima seedlings (Carrollton, $\mathrm{OH}$ ), which is the same planting that produced 72-76, 'Amy', and 'Gideon'. Its mother was acquired from Ackerman Nursery, Bridgman, MI, in 1957. Its main attribute is consistent production of medium to large nuts with a distinct "peach fuzz" on the shell. The tree tends to fall flower, which tends to reduce the next year's yield. Its flavor is typical (Miller, 2003).

'Perry' (C. mollissima), also as known as Byron 93, was also selected from the old orchard at the Southeastern Fruit and Tree
Nut Research Laboratory in Byron, GA. The tree is attractive, has good productivity, and good-quality small to medium nuts (Nave, 2017).

'Precoce Migoule' $(C$. sativa $\times C$. cren$a t a$ ) is a vigorous, productive French cultivar. It is pollen-fertile, but heavy crop loads make tight crotch angles vulnerable to breakage. Its nuts $(\approx 17 \mathrm{~g}$ in California) have good flavor and peel well, but some have multiple embryos (Nave, 1998). Field resistance to phytophthora root rot is noted (Craddock and Perkins, 2019).

'Qing' (C. mollissima) was discovered as a yard tree in Hickory, Kentucky, where it was planted sometime between the late 1950s and early 1960s. Its origin is unknown, but it may have originated from trees distributed by the Tennessee Valley Authority. In 1998, it was named by $M$. Nave and propagated by G. Miller. Compared with adjacent $C$. mollissima trees, it is a much smaller tree. The tree is a heavy producer and has a desired "loose" canopy architecture. Nuts (medium to large) fall during the early to mid-season and are shiny and dark brown. Some burs have more than three nuts, which decreases the average nut size slightly. 'Qing' nuts have good flavor and are exceptionally sweet; they are sweeter than most $C$. mollissima nuts growing in the United States Multiple embryos are minimal or absent, and the nuts store very well, even for a C. mollissima nut (Miller, 2003; Nave, 1998). 'Qing' shows minimal blossom end rot. Grafts often experience delayed failure or poor growth. 'Qing' has performed highly consistently in UMCA trials, showing the best spring frost avoidance (Gold and Hunt, 2002).

'Schlarbaum' $(C$. crenata $\times C$. mollissima) is a M. Nave selection. The tree is tall, slender, and drops nuts mid-season. During the late 1990 s or early 2000 , Dr. Schlarbaum of the University of Tennessee grafted Japanese chestnut trees at the experimental station in Byron, GA. M. Nave collected and evaluated large seeds from these $C$. crenata grafts, and 'Schlarbaum' is a selection from that seedlot. The pollen parent was probably a neighboring $C$. mollissima tree with a large nut, and experts suspect that tree may be the cultivar Shandong (Byron 4-2). 'Shandong' had very large nuts (the second-largest nuts at Byron). 'Schlarbaum' has few male flowers that are mostly sterile, but its productivity is just average. Its nuts are very large, with an easily removeable pellicle (Anagnostakis and Nave, 2015; Miller, 2017). 'Scharlbaum' ramets were introduced to the UMCA repository in 2020.

'Shing' (C. mollissima) is a seedling selected from Yixian, China, and originated from the same seed lots as 'Yixian Large Nut'. It is a very vigorous tree and a precocious but variable producer. The nuts are small but very tasty (Metaxas, 2013; Nave, 2017).

'Simpson' $(C$. mollissima $\times C$. sativa $)$ is a cultivar with a moderate nut size. Its flavor is not remarkable and is lesser than that of the Gellatly hybrids. Many of the larger nuts have multiple embryos, which is problematic 
because they produce many small nuts (Nave, 1998).

'Sleeping Giant' $(C$. mollissima $\times C$. crenata $\times C$. dentata $)$ is a seedling derived from a $C$. mollissima $\times(C$. crenata $\times C$. dentata) cross at the Connecticut Agricultural Experiment Station in 1937 (Nave, 1998). It ripens during early to mid-season. Nuts with a good flavor are $\approx 11$ to $12 \mathrm{~g}$ in northern environments and 13 to $16 \mathrm{~g}$ in New Franklin, MO. Yields and nut size are relatively consistent, and some growers indicate that 'Sleeping Giant' shows good transferability between environments (Miller, 2003). Blossom end rot susceptibility has been observed in Missouri.

'Szego' $\{[C$. crenata $\times$ C. pumila $(\mathrm{L})$. Mill. $] \times C$. mollissima hybrid $\}$ is an OP seedling of the California hybrid 'Linden' $(C$. crenata $\times C$. pumila), and the Dunstan hybrid 'Revival' is speculated to be the pollen parent. The cultivar, named after New York Northern Nut Growers Association member Al Szego, is very vigorous and upright. It has a "loose" crown architecture that allows for preferred light penetration into the canopy. This architecture contributes to the cultivar's good productivity, despite producing ample male flowers. Nuts from 'Szego' are uniformly large $(>20 \mathrm{~g})$, easy to peel, and slightly less dense than typical C. mollissima nuts. They are also some of the best cultivars for eating, with a sweet and very flavorful taste. The nuts drop during the late season and store very well. In northern environments (like Iowa), the nuts do not drop from the burs. The tree is resistant to phytophthora root rot. However, ramets undergoing longterm evaluation at UMCA recently developed severe blight cankers; this cultivar is susceptible to blight. 'Szego' is very cold-hardy, more so than many C. mollissima. Growers in Iowa, Michigan, and Ohio note that 'Szego' has survived winter conditions that have killed many other $C$. mollissima cultivars (Miller, 2017).

'Vancouver' (C. mollissima) is an early selection of M. Nave's grown from a seed that originated in Vancouver, Canada. The tree is still young, but its large, flavorful chestnuts make it stand out. Ramets have been incorporated in the UMCA repository. Greater evaluations in the East and Midwest are needed. 'Vancouver' ramets were introduced to the UMCA repository in 2020.

'WC' $(C$. mollissima $\times C$. pumila $)$ is named after W. C. Donoho of Louisville, KY, a member of the Kentucky Nut Growers Association. The tree is possibly a sibling of 'Qing'. Its large, dark nuts resemble those of 'Qing' because they are similar in size and sweetness and store well. 'WC' is more vigorous than 'Qing' and may graft more easily (Nave, 2017). 'WC' ramets were introduced to the UMCA repository in 2020.

'Willamette' (C. mollissima) is another OP offspring selected from among the widely available Dunstan population. The population is derived from a putative and lost $C$. dentata tree (described as blight-resistant) and three C. mollissima cultivars 'Nanking', 'Kuling', and 'Meiling' (morphological characteristics and DNA markers indicate no $C$. dentata ancestry in the Dunstan population). The tree has an upright growth habit and matures during the mid-season to late season in Missouri. The flavor of the nut is slightly unusual, and the nut is better cooked than raw, which is a characteristic it shares with one of its probable ancestors, 'Meiling'. Its nuts usually have double embryos and were inconsistent in size in Missouri, where they are often very small (Gold and Hunt, 2002; Nave, 1998).

'Yixian Good Flavor' (C. mollissima), also referred to as 'YGF', originated from a seedlot from the region of Yixian, China, in the southern tip of Anhui Province. The tree grows upright, and the nuts drop over the course of an extended time, from early season to late season. 'Yixian Good Flavor' produces a very flavorful, medium to large nut. Its nuts are some of the larger $C$. mollissima nuts grown at the University of Missouri chestnut planting in New Franklin (Nave, 2017). More evaluations in the East and Midwest are needed.

'Yixian Large Nut' (C. mollissima) is a selection made in 1993 by M. Nave. The seedling originated from a seedlot of large nuts from Yixian, Anhui Province, China, in the southern tip of Anhui Province, and it is possibly a sibling of 'Shing'. True to its name, the cultivar produces a large nut $(\approx 20$ $\mathrm{g}$ in Missouri) with good flavor, although nut size varies by environment. The pellicle removes well, and the nuts drop over a long period, from early to late season (Anagnostakis, 2015; Nave, 2017). More evaluations in the East and Midwest are needed.

'Yixian Orange' $(C$. mollissima $)$ is also a selection made in 1993 by $M$. Nave. The seedling originated from a seedlot of small nuts from Yixian, Anhui Province, China (a different source than that of 'Yixian Large Nut') (Nave, 2017). It is pollen-fertile and not a heavy pollen producer. Its bright orange nuts are medium in size, drop during midseason to late season, exhibit good pellicle removal, and have excellent flavor (Anagnostakis and Nave, 2015). More evaluations in the East and Midwest are needed.

\section{Literature Cited}

Anagnostakis, S.L. 2012. Chestnut breeding in the United States for disease and insect resistance. Plant Dis. 96:1392-1403, https://doi.org/10.1094/ PDIS-04-12-0350-FE.

Anagnostakis, S.L. and J.M. Nave. 2015. New named chestnut cultivars, and a few updates on previously named cultivars. Ann. Rpt. Northern Nut Growers Assn. 105:3-5.

Colby, A.S. 1924. Notes by Professor A.S. Colby. Annu. Rpt. Northern Nut Growers Assn. 15:93-103.

Colby, A.S. 1936. The chestnut situation in Illinois. Annu. Rpt. Northern Nut Growers Assn. 27:99-100.

Craddock, J.H. and S. Pellegrino. 1992. Recent introduction of European chestnut varieties into the USA. p. 197-201. In: Proc. International Chestnut Conference, Morgantown, West Virginia, 10-14 July 1992.
Craddock, J. and T.M. Perkins. 2019. Chestnut (Castanea spp. Miller) breeding, p. 105-156. In: J.M. Al-Khayri, S.M. Jain, and D.V. Johnson (eds.). Advances in plant breeding strategies: Nut and beverage crops. Springer, Switzerland.

Fei, S., L. Liang, F.L. Paillet, K.C. Steiner, J. Fang, Z. Shen, Z. Wang, and F.V. Hebard. 2012 Modeling chestnut biogeography for American chestnut restoration. Divers. Distrib. 8:754-768, https://doi.org/10.1111/j.1472-4642.2012.00886.x.

Fulbright, D.W. 2021. Michigan cultivars. Michigan State University Extension. 1 June 2021. https:// www.canr.msu.edu/chestnuts/horticultural_care/ michigan-cultivars.

Gellatly, J.U. 1964. Timber type chestnut trees. Ann. Rep. North. Nut Growers Assoc. 55:30-32.

Gold, M. and K. Hunt. 2002. Growing chestnut in Missouri. Ann. Rpt. Northern Nut Growers Assoc. 93:20-26.

Hunt, K.L., M.A. Gold, and M.R. Warmund. 2004. Chinese chestnut cultivar performance in Missouri. III International Chestnut Congress 693:145-148, https://doi.org/10.17660/ ActaHortic.2005.693.15.

Hunt, K., M. Gold, W. Reid, and M. Warmund. 2012. Growing Chinese chestnut in Missouri (revised) agroforestry in action guide, AF1007 2012. University of Missouri Center for Agroforestry, Columbia. $16 \mathrm{p}$.

Jaynes, R.A. 1970. The Eaton Chestnut -a new cultivar. Annu. Rpt. Northern Nut Growers Assn. 61:82-83.

LaBonte, N.R., P. Zhao, and K. Woeste. 2018. Signatures of selection in the genomes of Chinese chestnut (Castanea mollissima Blume): The roots of nut tree domestication. Frontiers in Plant Sci. 9:810, https://doi.org/10.3389/ fpls.2018.00810.

McCleary, T., M. McAllister, M. Coggeshall, and J. Romero-Severson. 2013. EST-SSR markers reveal synonymies, homonymies and relationships inconsistent with putative pedigrees in chestnut cultivars. Genet. Resources Crop Evol. 60:1209-1222, https://doi.org/10.1007/ s10722-012-9912-9.

Metaxas, A.M. 2013. Chestnut (Castanea spp.) cultivar evaluation for commercial chestnut production in Hamilton County, Tennessee. M.S. Thesis Univ. Tennessee-Chattanooga.

Miller, G. 2003. Chestnuts, p. 167-181. In: D. Fulbright (ed.). A guide to nut tree culture in North America. Northern Nut Growers Assoc., USA.

Miller, G. 2016. Cooperative chestnut breeding in the USA. Chestnut Growers of America. 16 Nov. 2020. <http://www.chestnutgrowers.org/ GregMiller-CooperativeBreeding.pdf $>$.

Miller, G. 2017. Breeding chestnuts for nut quality and yield in eastern North America: a cooperative breeding program. Northern Nut Growers Assoc. Fall Rpt.

Mori, G.O., M. Gold, and S. Jose. 2017. Specialty crops in temperate agroforestry systems: Sustainable management, marketing and promotion for the midwest region of the USA, p. 331-366. In: F. Montagnini (ed.). Integrating landscapes: agroforestry for biodiversity conservation and food sovereignty. Springer, Switzerland.

Nave, J.M. 1998. Large-fruited chestnuts grown in North America. Ann. Rpt. Northern Nut Growers Assoc. 89:42-82.

Nave, J.M. 2017. Interesting new chestnut cultivars. Chestnut growers of America. 16 Nov. 2020. $<$ http://www.chestnutgrowers.org/MikeNaveNewCultivars.pdf>

Norton, J.D., A.G. Hunter, and H. Harris. 1983. Research with Chinese chestnut in Alabama 
(Castanea mollissima). Ann. Rpt. Northern Nut Growers Assoc. 74:151-155.

Rutter, P.A., G. Miller, and J.A. Payne. 1991. Chestnuts (Castanea). Genetic Resources of Temperate Fruit and Nut Crops 290:761-790, https:// doi.org/10.17660/ActaHortic.1991.290.17.

Seligmann, E. 1994. Search for 'Carr' Chinese chestnut. Ann. Rpt. Northern Nut Growers Assoc. 48:94.
Torello-Marinoni, D., S. Nishio, E. Portis, N. Valentini, C. Sartor, F. Dini, P. Ruffa, S. Oglietti, G. Martino, and A. Akkak. R. Botta. 2018. Development of a genetic linkage map for molecular breeding of chestnut. VI International Chestnut Symposium 1220:23-28, https://doi.org/10.17660/ ActaHortic.2018.1220.4.
USDA National Agricultural Statistics Service. 2018. Noncitrus fruits and nuts 2017 summary. 1 Dec. 2020. <https://www.nass.usda.gov/Publications/ Todays_Reports/reports/ncit0618.pdf>.

Wang, C. 2004. Ban Li (Chestnut). Joumal of the American Chestnut Foundation. Translated from: Anonymous, 1979. Chestnut, Science Publishing House, Beijing Institute of Botanical Research, Jiangsu 38:17. 